\title{
Immunohistochemical investigation of Foxp3 expression in the intestine in healthy and diseased dogs
}

\author{
Johannes Junginger ${ }^{1}$, Ulrike Schwittlick', Frederik Lemensieck², Ingo Nolte ${ }^{3}$ and Marion Hewicker-Trautwein ${ }^{1 *}$
}

\begin{abstract}
Intestinal immune regulation including development of oral tolerance is of great importance for the maintenance of intestinal homeostasis. Concerning this, regulatory T cells (Tregs) occupy a pivotal role in cell-mediated immunosuppression. Dysregulation of mucosal immunology leading to an abnormal interaction with commensal bacteria is suggested to play a key role in the pathogenesis of Inflammatory Bowel Disease (IBD) in men and dogs. The aim of this study was to characterise the expression of Foxp3 in the normal canine gut of 18 dogs (mean age: 6.03 years), in 16 dogs suffering from IBD (mean age: 5.05 years), and of 6 dogs with intestinal nematode infection (mean age: 0.87 years) using immunohistochemistry. In the duodenum, Tregs in healthy dogs declined from villi (median: 10.67/62 $500 \mathrm{\mu m}^{2}$ ) to crypts (median: 1.89/62 $500 \mu \mathrm{m}^{2}$ ). Tregs were further increased in the villi of middleaged dogs (median: 18.92/62 $500{\mu m^{2}}^{2}$ ) in contrast to juvenile (median: 3.50/62 $500 \mu^{2}$ ) and old (median: 9.56/62 $500 \mathrm{\mu m}^{2}$ ) individuals. Compared to healthy controls, animals suffering from IBD revealed reduced numbers of Tregs in duodenal villi (median: 4.13/62 $500 \mathrm{\mu m}^{2}$ ). Dogs with intestinal nematode infection displayed increased numbers of Tregs (median: 21.06/62 $500 \mathrm{\mu m}^{2}$ ) compared to healthy animals.

Age-related changes indicate a progressive establishment of oral tolerance and immunosenescence in the canine elderly. The results further suggest that a defect in Treg homeostasis may be involved in the pathogenesis of canine IBD. In contrast, increased numbers of Tregs in the duodenum may be due to nematode infection.
\end{abstract}

\section{Introduction}

The vertebrate's gut is perpetually exposed to an enormous amount of different microorganisms and food proteins with antigenic properties that are essential for the individual's life. Concerning this high antigenic load, a complex immunological network has been developed representing an effective protection composed of more structured areas (lymphoid aggregates, Peyer's patches, lymphoglandular complexes, and mesenteric lymph nodes) as well as diffuse parts (lamina propria leucocytes and intraepithelial lymphocytes) [1-4]. Due to the intestinal colocalisation of commensal bacteria and pathogens, mechanisms preventing specific immune responses against orally administrated antigens (e.g. food proteins and commensal bacteria) termed as oral tolerance are as

\footnotetext{
* Correspondence: Marion.Hewicker-Trautwein@tiho-hannover.de 'Institute of Pathology, University of Veterinary Medicine Hannover, Bünteweg 17, D-30559 Hannover, Germany Full list of author information is available at the end of the article
}

much as essential as the induction of specific immune responses against pathogenic organisms.

In general, immune regulation can be either mediated by regulatory cytokines (e.g. tissue growth factor (TGF) $-\beta$, interleukin (IL)-10) or cellular interactions. Today, it is well-known that specialised $\mathrm{T}$ helper cells with regulatory properties (Tregs) play an important part in immune regulation [5,6]. Depletion of these cells or mutations of related transcription factors provokes severe cases of autoimmune diseases and chronic inflammatory disorders as described in rats, mice, and men [7-10]. Furthermore, oral tolerance is supposed to be mainly mediated by the induction and expansion of Tregs in the context of specialised tolerogenic dendritic cells in the gut [11-13]. Alongside their regulatory capacity, Tregs are characterised by the expression of CD4, CD25 [7], and the highly conserved transcription factor Forkhead box P3 (Foxp3) [14] serving a pivotal role in stabilising their regulatory properties [15].

Canine idiopathic Inflammatory Bowel Disease (IBD) is a term used for a variety of disorders characterised by
C Biomed Central 
chronic persistent or recurrent gastrointestinal signs (e.g. vomiting, diarrhoea, and weight loss) with no underlying cause (e.g. parasitosis, bacterial infection, food allergy, lymphoma, or lymphangiectasia) and histological evidence of mucosal inflammatory infiltration [16-18].

In humans, idiopathic IBD is known as Crohn's disease (CD) or ulcerative colitis (UC) $[19,20]$. CD is characterised by transmural neutrophilic inflammation followed by granuloma formation commonly present in the terminal jejunum and ileum and is often complicated by intestinal or anal fistulae, strictures, obstructions, or intestinal perforations [21]. In UC, neutrophilic infiltration is restricted to the colonic and rectal mucosa and is associated with ulceration and crypt abscesses. In addition to intestinal lesions, extraintestinal manifestations (e.g. arthritis, renal disease, pyrexia, mucocutaneous lesions, hepatobiliary complications, or osteopenia) are often reported in human IBD [22].

In dogs, mucosal inflammation is the main histopathological feature of idiopathic IBD and variants are classically distinguished regarding their dominant cellular infiltrates $[17,23]$. Lymphoplasmacytic enteritis (LPE) represents the most common form of idiopathic IBD in dogs [24]. Additionally, eosinophilic gastroenteritis (EGE) characterised by a mixed infiltration of inflammatory cells with dominance of eosinophilic granulocytes is the second most frequently diagnosed form of canine IBD. Furthermore, several variants of LPE and EGE exist since inflammation can be restricted to one or more anatomical sites (e.g. stomach, small intestine, or colon). Additionally, histiocytic ulcerative colitis (HUC) is a rare colonic disorder reported in boxers that is characterised by the histological presence of PAS-positive macrophages within the colonic mucosa $[25,26]$ that is supposed to be associated with Escherichia coli [27]. Furthermore, idiopathic granulomatous intestinal inflammation characterised by infiltration of macrophages with granuloma formation similar to $\mathrm{CD}$ is rarely reported in dogs $[28,29]$. In contrast to human IBD, complications are rare in canine patients and only thrombocytopenia is discussed as an extraintestinal manifestation of IBD in dogs [30]. Although canine idiopathic IBD differs from CD and UC in humans in several aspects, a common pathogenesis is suggested. Idiopathic IBD is supposed to develop in a multilayer model including genetic factors [31-35], dysregulation of the immune system, and disturbances of the intestinal microflora leading to a breakdown of immunological tolerance to luminal antigens $[36,37]$.

Parasitic infections constitute common intestinal diseases with zoonotic potential in companion animals $[38,39]$. Possible clinical signs in dogs include vomiting, diarrhoea, abdominal pain, and weight loss, but clinical symptoms may be absent. Histopathologically, affected tissues reveal varying degrees of cellular infiltrations with prominence of eosinophilic granulocytes [40] and therefore share some histological features with canine idiopathic EGE. Immunologically, intestinal helminths trigger downregulation of the immune system ensuring longer survival in the host $[41,42]$. In murine models of nematode infection, Foxp3+ Tregs expand after application of parasites and correlate with the period of worm survival, but decrease after application of anti-CD25 antibodies that is associated with increased intestinal pathology [43-45]. Furthermore, excretory-secretory products of several parasites (Heligmosomoides polygyrus, Haemonchus contortus, and Teladorsagia circumcincta) are known to drive TGF- $\beta$-like signalling resulting in expansion of murine Foxp3+ Tregs in vitro and in the gutassociated lymphoid tissue (GALT) in vivo [46]. Interestingly, the administration of parasitic antigens is discussed as a possible treatment of human IBD due to their regulatory properties $[47,48]$.

Since the availability of specific antibodies, Foxp3 has been established as a specific marker for Tregs in different species $[49,50]$ and the literature concerning regulatory $\mathrm{T}$ cells in domestic animals has been increased [51]. In cats, CD4+ CD25+ Tregs have been characterised in detail in the context of the pathogenesis of feline immunodeficiency virus [52-55]. Tregs are also described and characterised in pigs [56-58], especially in linkage to foetal tolerance [59], renal and cardiac allotransplantation [60-62], and infection with porcine reproductive and respiratory syndrome virus $[63,64]$. Expression of Foxp3 is also reported in cows. Most of bovine Foxp3-positive cells coexpress CD4 and CD25 [65], although minor populations of CD $8 \beta+$ and $\gamma \delta+$ Foxp $3+\mathrm{T}$ cells with Foxp 3 expression have been described [66]. However, the regulatory properties of CD4+ CD25+ Foxp3+ bovine T cells are controversially discussed, since $\gamma \delta+\mathrm{T}$ cells and CD14+ monocytes but not CD4+ CD25+ Foxp3+ cells exhibited regulatory function in one study [67]. Additionally, ovine Foxp3 has recently been described and Foxp3 expressing cells are significantly increased in the skin of sheep infected with Psoroptes ovis [68]. Other species in which Foxp3 expression is described include the horse [69], baboon [70,71], macaque [72], chimpanzee [73], harbour seals and walrus [74], and zebrafish [75].

In dogs, the principle of peripheral tolerance was first suggested in 1976 as a specific population of T cells seeming to prevent graft-versus-host reaction [76]. In 2007, a subset of CD4+ T cells in blood and/or lymph nodes of dogs was detected using anti-mouse/rat Foxp3 monoclonal antibodies (clone FJK-16s) and authors suggested crossreactivity of these antibodies with canine Foxp3 [49]. Since then, the crossreactivity of this antimouse/rat Foxp3 antibody with canine Foxp3 has been 
confirmed by investigation of cell lines that overexpress the canine Foxp3 gene [77]. Additionally to Foxp3, specific antibodies against canine CD25 have been available for a few years [77-79] and therefore CD4+ CD25+ Foxp3+ T cells have been described in the canine peripheral blood $[77,80]$. Additionally, canine Foxp3+ Tregs were investigated in the context of neoplasia, atopic dermatitis, and adverse food reactions [49,81-87]. Recently, the regulatory function of canine CD4+ CD25+ Foxp3+ $\mathrm{T}$ cells was described in vitro $[79,80]$. Furthermore, there is evidence for heterogeneity of canine Tregs since those with high expression of Foxp3 are possibly activated Tregs in contrast to Tregs with intermediate expression of Foxp3, which are suggested to be a more heterogeneous population of predominantly activated conventional $\mathrm{T}$ cells [80]. Regarding the canine gastrointestinal tract, there is only one report about the expression of cytokines and transcription factors of different $\mathrm{T}$ cell subsets including Tregs in the duodenum of dogs. In this study, no alterations in gene expression were present in dogs with cutaneous food hypersensitivity compared to healthy controls [86]. Until today, no investigations of Foxp3 expression in canine idiopathic IBD, nor in canine nematode infections have been available.

The aim of the study was to investigate the expression of Foxp3 in the canine GALT in healthy animals and in dogs with chronic idiopathic IBD. Additionally, we investigated cases of canine intestinal nematode infections that share some histopathological features with canine idiopathic EGE.

\section{Materials and methods Animals}

For the evaluation of Foxp3-positive cells in the normal canine gut, 18 dogs without gastrointestinal diseases routinely submitted for necropsy to the Institute of Pathology (University of Veterinary Medicine, Hannover) were used (Table 1). These dogs were presented to the Small Animal Clinic of the University of Veterinary Medicine (Hannover) because of other problems than gastrointestinal symptoms. A detailed clinical workup (e.g. case history, clinical investigation, haematology, serum biochemistry, ultrasonics, and taking X-rays and MRI if necessary) was performed by the clinicians on these dogs and no gastrointestinal symptoms were present during this procedure. Additionally, only dogs without any pathomorphological signs of gastrointestinal disorders during necropsy were used as healthy controls. Tissue samples collected from different locations (gastric fundus, descending duodenum, middle of jejunum, ileum, descending colon, and mesenteric lymph node) were taken as soon as possible after euthanasia (approximately between 15 and 30 minutes post mortem), being immediately fixed in $10 \%$ neutral buffered formalin, and embedded in paraffin. Animals were grouped as juvenile (0.08 to 0.99 years), middle-aged (1.94 to 6.25 years), and old individuals (8.98 to 15.22 years).

For the investigation of Tregs in canine IBD, gastrointestinal biopsy specimen were obtained from 16 dogs suffering from chronic gastrointestinal disorders of unknown aetiology (ages ranging from 2.00 to 7.22 years) that were admitted to the Small Animal Clinic of the University of Veterinary Medicine (Hannover) as well as to another Small Animal Clinic (Duisburg Asterlagen, Table 2). Clinically, dogs were presented with chronic (at least 3 weeks) or recurrent vomiting (no. 1- 4, 6- 8, 13, 15 , and 16) and/or diarrhoea (no. 1, 2, 4-12, 14, and 15) partially in conjunction with emaciation (no. 7, 9, 12, 14, and 16). Detailed clinical workup was performed for every patient (including clinical examination, taking $\mathrm{X}$-rays, ultrasonics, haematology, serum biochemistry comprising determination of cobalamin, urinanalysis, microbiology and parasitology of faecal samples, and antimicrobial therapy including application of metronidazole). Several endoscopical biopsies (at least four per localisation) taken from the gastric fundus $(n=16)$, duodenum $(n=16)$, and colon $(n=8$; no. $1,2,4,9,12,13$, 15 , and 16) during routine diagnostics were fixed in $10 \%$ neutral buffered formalin and embedded in paraffin.

Furthermore, 6 dogs with spontaneous intestinal nematode infection detected by macroscopical and/or microscopical findings (age ranges from 0.18 to 1.25 years) were evaluated (Table 2). Clinically, no gastrointestinal symptoms were present in these dogs. Fox Terrier dogs (no. 17 and 18) were euthanised due to progressive paraparesis and routinely submitted for necropsy to the Institute of Pathology (University of Veterinary Medicine, Hannover). Beagle dogs (no. 19-22) were humanely destroyed for reasons unrelated to the present study followed by macroscopical and histopathological examination. Tissue specimens were taken as soon as possible after euthanasia (approximately between 15 and $30 \mathrm{~min}$ post mortem) from gastric fundus, descending duodenum, and descending colon and each were immediately processed as described above.

\section{Histopathological examination}

For histopathological examination, 2-4 $\mu \mathrm{m}$ thin sections were prepared and stained with haematoxylin and eosin (H\&E) by standard histological procedures. Slices were independently evaluated by 3 pathologists (JJ, US, MHT) using light microscopes (Carl Zeiss) according to the histopathological guidelines for the evaluation and scoring of canine intestinal inflammation recently published by the World Small Animal Veterinary Association (WSAVA) Gastrointestinal Standardisation Group [88]. Concerning dogs used as healthy controls and dogs with intestinal nematode infection, only samples with no or minimal signs of autolysis were included in this study ensuring that 
Table 1 Dogs without gastrointestinal diseases.

\begin{tabular}{|c|c|c|c|c|c|c|}
\hline No. & Breed & Age (years) & Age group & WSAVA total & WSAVA part & Reason for euthanasia \\
\hline 1 & Leonberger & 0.08 & juvenile & 1 & 1 & Oesophageal dilatation \\
\hline 2 & Labrador & 0.20 & juvenile & 4 & 2 & Oesophageal dilatation \\
\hline 3 & Alsatian & 0.22 & juvenile & 0 & 0 & Seizures \\
\hline 4 & Pinscher & 0.52 & juvenile & 3 & 1 & Ataxia \\
\hline 5 & Briard & 0.99 & juvenile & 0 & 0 & Ataxia \\
\hline 6 & Jack Russel Terrier & 1.94 & middle-aged & 3 & 3 & Right hemiparesis \\
\hline 7 & Siberian Husky & 4.00 & middle-aged & 6 & 3 & Seizures \\
\hline 8 & Kuvasz & 4.28 & middle-aged & 0 & 0 & Vertebral sarcoma \\
\hline 9 & Australian Shepherd & 4.43 & middle-aged & 3 & 3 & GME \\
\hline 10 & Pointer & 5.85 & middle-aged & 3 & 0 & Hypophyseal adenoma \\
\hline 11 & Pyrenean Shepherd & 6.09 & middle-aged & 2 & 2 & Spinal disk herniation \\
\hline 12 & Yorkshire Terrier & 6.25 & middle-aged & 4 & 4 & NLE \\
\hline 13 & Beagle & 8.98 & old & 4 & 4 & Tonsillar SCC \\
\hline 14 & Crossbreed & 10.16 & old & 2 & 2 & GME \\
\hline 15 & Crossbreed & 12.00 & old & 4 & 3 & Haemangiosarcoma \\
\hline 16 & Alsatian & 12.85 & old & 6 & 4 & Spinal disk herniation \\
\hline 17 & Crossbreed & 14.77 & old & 3 & 2 & $\mathrm{HCM}$ \\
\hline 18 & Crossbreed & 15.22 & old & 1 & 1 & Pancreatic adenocarcinoma \\
\hline
\end{tabular}

WSAVA = histopathological score regarding the guidelines for evaluation and scoring of canine intestinal inflammation of the World Small Animal Veterinary Association (WSAVA) Gastrointestinal Standardization Group. WSAVA total = WSAVA score of the total gastrointestinal tract (including stomach, duodenum, jejunum, ileum, and colon). WSAVA part = WSAVA score of the stomach, duodenum, and colon (for comparison with WSAVA scores of dogs with gastrointestinal diseases). GME granulomatous meningoencephalitis. NLE necrotizing leucoencephalitis. SCC squamous cell carcinoma. HCM hypertrophic cardiomyopathy.

Table 2 Dogs with inflammatory gastrointestinal diseases.

\begin{tabular}{|c|c|c|c|c|c|}
\hline No. & Breed & Age (years) & Age group & WSAVA score & Disease \\
\hline 1 & Crossbreed & 2.00 & middle-aged & 6 & EGE \\
\hline 2 & Hungarian Vizslar & 2.75 & middle-aged & 14.5 & EGEC \\
\hline 3 & Crossbreed & 3.00 & middle-aged & 7 & $\mathrm{EE}$ \\
\hline 4 & Crossbreed & 4.60 & middle-aged & 12 & EGEC \\
\hline 5 & Border Collie & 4.76 & middle-aged & 5 & $\mathrm{EE}$ \\
\hline 6 & Irish Terrier & 7.00 & middle-aged & 7 & EGE \\
\hline 7 & Crossbreed & 7.00 & middle-aged & 5.5 & EGE \\
\hline 8 & Hovawart & 2.33 & middle-aged & 8 & LPGEC \\
\hline 9 & Malinois & 4.00 & middle-aged & 8.5 & LPGE \\
\hline 10 & Belgian Shepherd & 4.50 & middle-aged & 7.5 & LPGE \\
\hline 11 & Jack Russel Terrier & 5.24 & middle-aged & 8 & LPGEC \\
\hline 12 & Boxer & 6.00 & middle-aged & 9 & LPEC \\
\hline 13 & Crossbreed & 6.50 & middle-aged & 7.5 & LPGE \\
\hline 14 & WHWT & 6.82 & middle-aged & 15.5 & LPGEC \\
\hline 15 & Poodle & 7.00 & middle-aged & 4.5 & LPGEC \\
\hline 16 & Crossbreed & 7.22 & middle-aged & 4.5 & LPGE \\
\hline 17 & Fox Terrier & 0.18 & juvenile & 11 & $\mathrm{Nl}$ \\
\hline 18 & Fox Terrier & 0.18 & juvenile & 8 & $\mathrm{NI}$ \\
\hline 19 & Beagle & 1.17 & juvenile & 3 & $\mathrm{NI}$ \\
\hline 20 & Beagle & 1.17 & juvenile & 6 & $\mathrm{NI}$ \\
\hline 21 & Beagle & 1.25 & juvenile & 10 & $\mathrm{NI}$ \\
\hline 22 & Beagle & 1.25 & juvenile & 11 & $\mathrm{NI}$ \\
\hline
\end{tabular}

WHWT $=$ West Highland White Terrier. EE $=\mathrm{IBD}$, eosinophilic enteritis. EGE = IBD, eosinophilic gastroenteritis. EGEC = IBD, eosinophilic gastroenterocolitis. LPE = IBD, lymphoplasmacytic enteritis. LPGE = IBD, lymphoplasmacytic gastroenteritis. LPEC = IBD, lymphoplasmacytic enterocolitis. LPGEC = IBD, lymphoplasmacytic gastroenterocolitis. $\mathrm{NI}=$ intestinal nematode infection. 
they were comparable to endoscopical biopsy specimens (Figure 1a-d).

\section{Immunohistochemistry}

For immunohistochemistry, 2-4 $\mu \mathrm{m}$ thin sections were dewaxed in Rotihistol (Roth C. GmbH \& Co. KG, Karlsruhe, Germany) and rehydrated in descending ethanol series. Blocking of endogenous peroxidase was achieved by incubation of the sections in $\mathrm{H}_{2} \mathrm{O}_{2} 0.5 \%$ in ethanol for $30 \mathrm{~min}$. Antigen retrieval was performed with citrate buffer ( $\mathrm{pH} 6.0,20 \mathrm{~min}, 95^{\circ} \mathrm{C}$ ) followed by the application of normal rabbit serum for $30 \mathrm{~min}$. Sections were then incubated with anti-mouse/rat Foxp3 antibodies (1 in 400 dilution; clone FJK-16s, eBioscience, San Diego, CA) overnight at $4^{\circ} \mathrm{C}$ that have shown to detect canine Foxp3 using flow cytometry [49,77] and immunohistochemistry [89], followed by secondary antibody application (biotinylated rabbit anti-rat IgG $[\mathrm{H}+\mathrm{L}]$; Vector Laboratories, Burlingame, California) for $30 \mathrm{~min}$. Subsequently, avidin-biotin complex (Vector Laboratories) was utilised for $30 \mathrm{~min}$. Accordingly, biotinylated tyramine was applied to intensify the reaction followed by a second incubation with an avidin-biotin complex. Between each step, sections were rinsed three times in phosphate buffered saline (PBS; $\mathrm{pH}$ 7.2, $0.15 \mathrm{M}$ ). 3,3'-diaminobenzidine and $\mathrm{H}_{2} \mathrm{O}_{2}$ was applied for $5 \mathrm{~min}$ to generate a brown colour reaction. Sections
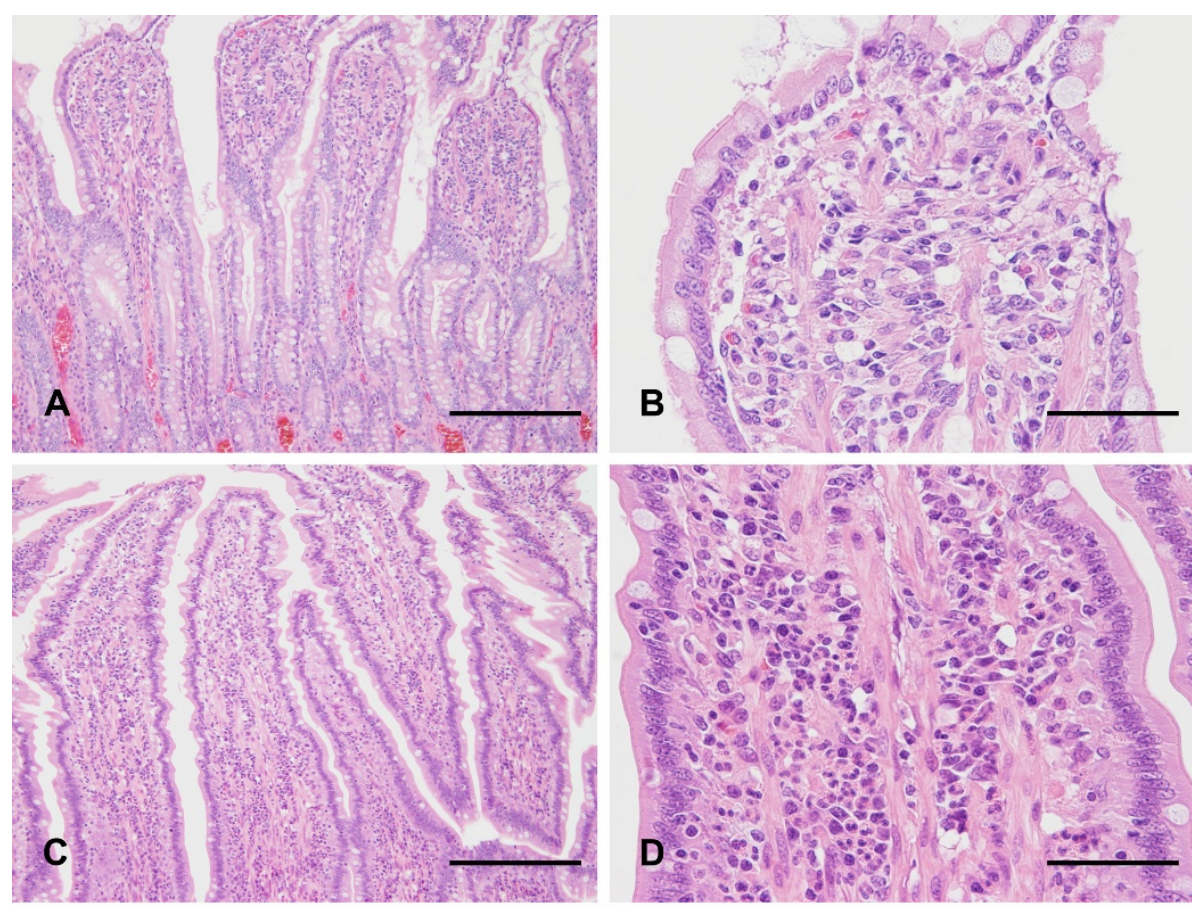

B 50.000
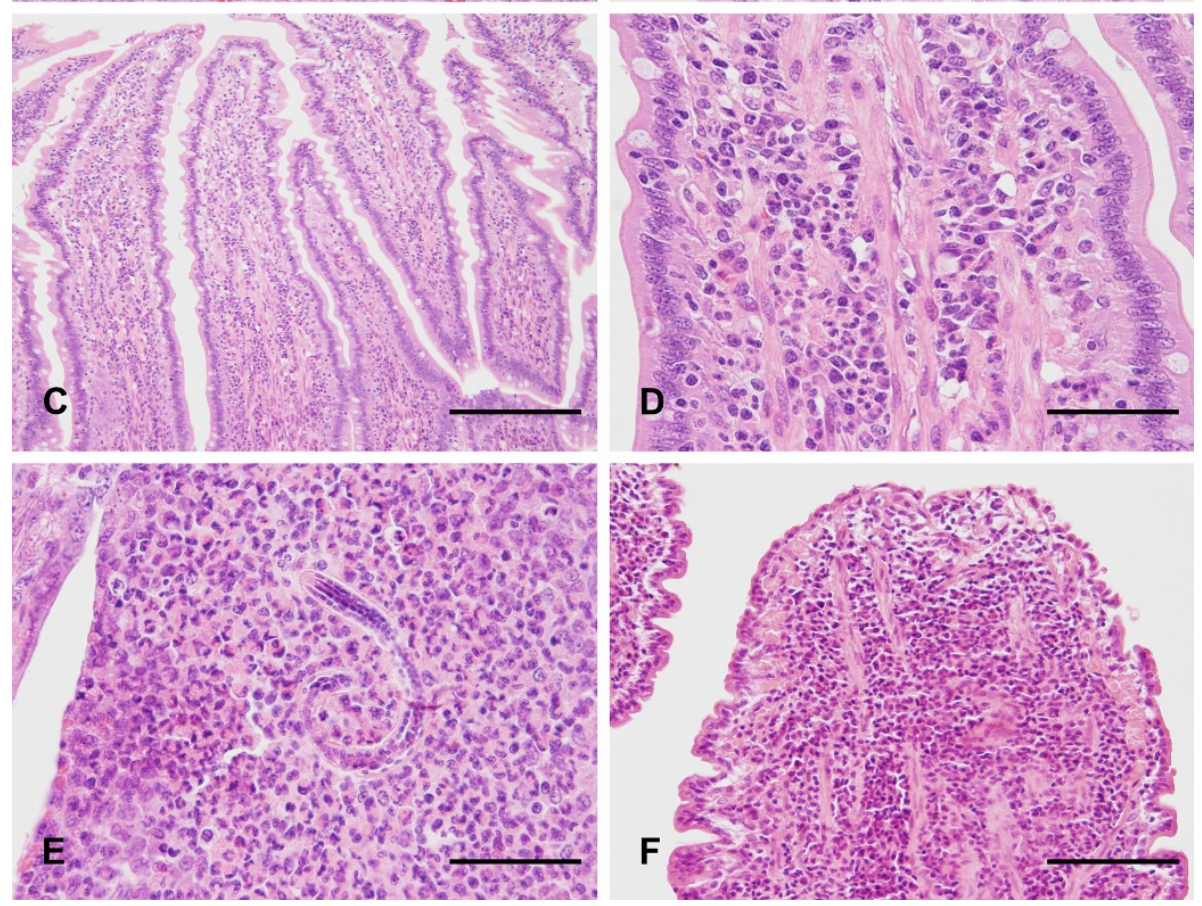

Figure 1 Histology of dogs without gastrointestinal symptoms and of dogs suffering from gastrointestinal diseases. Intestinal samples of dogs used as healthy controls (A: dog no. 8, bar: $200 \mu \mathrm{m}$; B: dog no. 8, bar: $50 \mu \mathrm{m}$ ) and of dogs with intestinal nematode infection (C: dog no. 20, bar: $200 \mu$ m; D: dog no. 20, bar: $50 \mu \mathrm{m}$ ) revealed comparable freshness to intestinal biopsy specimens. In dogs with intestinal nematode infection, mucosal inflammation was dominated by eosinophilic granulocytes in addition to increased amounts of lymphocytes, plasma cells, and neutrophils (D: dog no. 20, bar: 50 mm). Furthermore, parasitic structures resembling nematode larvae were occasionally present within inflammatory foci (E: dog no. 20, bar: $50 \mu \mathrm{m}$ ). In dogs with LPE, intestinal mucosa was infiltrated by lymphocytes and plasma cells (F: dog no. 9, bar: $100 \mu \mathrm{m})$. 
were counterstained with Mayer haematoxylin. Sections of normal canine thymus and mandibular lymph node were used as positive controls. The primary antibody solution was substituted with normal rat serum as a negative control.

\section{Examination of sections}

Cells revealing clear lymphocyte morphology with distinct nuclear staining for Foxp3 but unstained cytoplasm (interpreted as Tregs) were quantified in different compartments (gastric fundus: lamina propria; small intestine: villus, basal crypt area, villus-crypt junction; large intestine: apical crypt area, basal crypt area) using a light microscope (Carl Zeiss), $\mathrm{a} \times 40$ objective, $\mathrm{a} \times 10$ eyepiece, and a square eyepiece graticule $\left(10 \times 10\right.$ squares, with a total area of $\left.62500 \mu^{2}\right)$. Ten appropriate sites were chosen for each compartment and arithmetic means were calculated for each one. The results are expressed as positive cells per $62500 \mu^{2}$.

\section{Statistical analysis}

Statistical analyses were performed using $\mathrm{R}$ version 2.13.1 (The R Foundation for Statistical Computing, Vienna, Austria). Primarily, each group was assessed for normal distribution using a histogram, Q-Q plot, and ShapiroWilk test. Kruskal-Wallis test and/or Wilcoxon rank-sum test were used to evaluate differences in WSAVA scores between different age groups in healthy dogs as well as between dogs with gastrointestinal diseases and controls. Furthermore, statistical significant differences in the numbers of Foxp3-positive cells between groups concerning different ages, localisations, and compartments as well as between diseased dogs and healthy controls were assessed using the Kruskal-Wallis test and Wilcoxon rank-sum test for independent samples or the Friedman test and Wilcoxon signed-rank test for related ones. Furthermore, the Spearman's rank correlation coefficient was used to investigate the relationship between intestinal Foxp3-positive cells in dogs with IBD and the WSAVA score for the appropriate intestinal section. $P$ values $\leq 0.05$ were defined as statistically significant.

\section{Results}

\section{Histopathological findings}

In dogs lacking clinical and pathomorphological signs of gastrointestinal diseases, mild histopathological findings were present in the gut (e.g. mild increases in lamina propria lymphocytes and plasma cells, crypt abscesses, crypt dilation, and mucosal fibrosis). These findings are summarised in Table 1 given as WSAVA scores. In these animals, no significant differences between the WSAVA scores of different groups of age were present.

Endoscopical biopsy specimens of dogs with chronic or recurrent gastrointestinal disorders revealed histopathological evidence of mucosal inflammation (Figure 1f). Therefore idiopathic IBD was diagnosed since other possible aetiologies were excluded (e.g. parasitic disease, bacterial infection, food allergy, antibiotic-responsive diarrhoea, lymphangiectasia, or neoplasia). Cellular infiltrates were either composed of lymphocytes and plasma cells $(n=9)$ or mixed inflammatory cells with prominence of eosinophilic granulocytes $(n=7)$.

In dogs with intestinal nematode infection, mucosal inflammation was dominated by eosinophilic granulocytes in addition to increased amounts of lymphocytes, plasma cells, and neutrophils (Figure 1d). Furthermore, parasitic structures resembling nematode larvae were occasionally present within inflammatory foci (Figure 1e).

Compared to healthy controls, WSAVA (summarised in Table 2) were significantly increased in dogs suffering from IBD $(p<0.001)$ and in animals with intestinal nematode infections $(p<0.01)$.

\section{Foxp3 expression in the canine gut of healthy dogs}

In healthy dogs, Foxp3 was expressed in both structured and diffuse parts of the canine GALT. Concerning Peyer's patches, Foxp3-positive cells were numerously present in interfollicular areas and lower amounts were visible in dome areas (Figure 2a). Only a few cells were located at the margin of B cell follicles. In gastric lymphoid aggregates as well as in colonic lymphoglandular complexes, Foxp3-positive cells were randomly distributed around the follicles. Mesenteric lymph nodes revealed high amounts of Foxp3-positive Tregs that were largely present in the paracortex as well as in the medullary sinus. In diffuse parts of the canine GALT, Foxp3 was expressed by both lamina propria lymphocytes as well as intraepithelial lymphocytes.

Numbers of Foxp3 expressing lymphocytes in the gut of healthy dogs are summarised in Table 3 given as medians per group. Without consideration of different age groups, the numbers of lamina propria Foxp3-positive lymphocytes were significantly increased in villi compared to basal crypt areas and the villus-crypt junction $(p<0.001$, Figure $2 \mathrm{~b}$ and $3 \mathrm{a}-\mathrm{c}$ ) in healthy animals. Furthermore, the density of Foxp3-positive lymphocytes was significantly higher in the basal crypt area than in the villus-crypt junction $(p<0.05)$. In the colon, Foxp3-expressing cells were increased in the basal crypt areas compared to the apical areas $(p<0.05$, Figure $3 d)$.

In healthy dogs disregarding their age, villus lamina propria Foxp3-positive cells were significantly decreased in the jejunum and the ileum compared to the duodenum $(p<0.001$, Figure 3e). In contrast to this, differences between the localisations of the small intestine were neither detected in the basal crypt area nor the villuscrypt junction.

Furthermore, canine intestinal Tregs revealed differences in their staining intensity for Foxp3 independent 


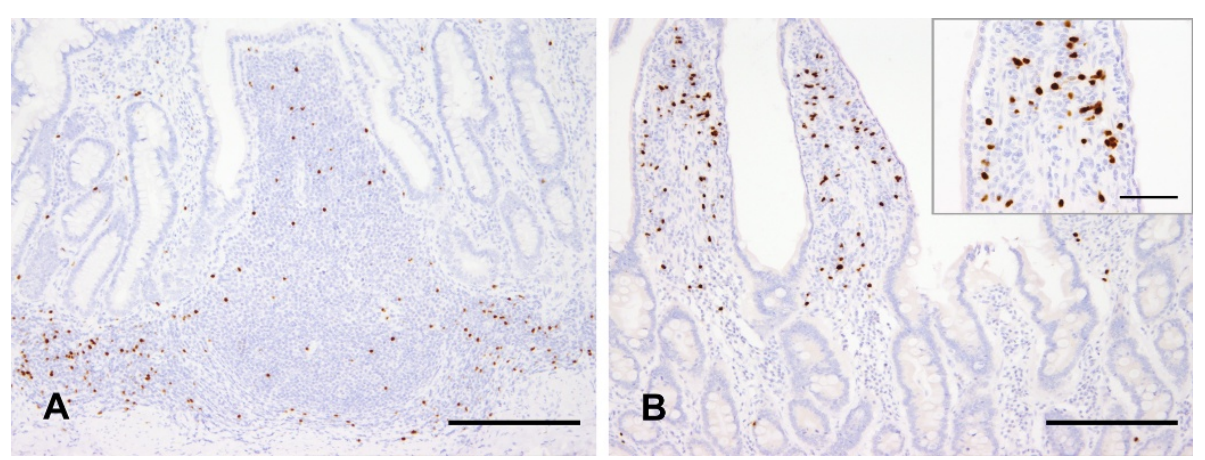

Figure 2 Foxp3 expression in the canine healthy GALT. In canine Peyer's patches, Foxp3-positive cells were numerously present in interfollicular areas and lower amounts were visible in dome areas. Only few cells were located at the margin of B cell follicles (A: jejunum, dog no. 10, bar: $200 \mu \mathrm{m})$. Regarding the small intestinal lamina propria, Foxp3-expressing lymphocytes were more numerous in the villus compared to crypts (B: ileum, dog no. 8, bar: $200 \mu \mathrm{m}$, inset bar: $50 \mu \mathrm{m}$ ).

of their localisation, i.e. some lymphocytes revealed weak nuclear staining and some lymphocytes had strongly labelled nuclei.

\section{Age-related changes in canine intestinal Foxp3 expression}

In healthy dogs, the number of villus Foxp3-positive lymphocytes were significantly increased in middle-aged dogs compared to juvenile as well as old animals in the duodenum and the jejunum ( $p<0.05$, Figure $3 \mathrm{f}-\mathrm{h})$. In the basal crypt area, an increase in Foxp3-expressing lymphocytes was detected in the jejunum between middleaged and juvenile dogs $(p<0.05)$. In the animals examined, no significant differences in Foxp3 expression between different age groups were present in the villuscrypt junction, ileum, gastric fundus, and colonic lamina propria.

Table 3 Foxp3 expressing lymphocytes in dogs without gastrointestinal diseases.

\begin{tabular}{cccccc}
\hline Localisation & Compartment & Total & Juvenile & Middle-aged & Old \\
\hline stomach & la pro & 1.13 & 0.60 & 1.31 & 0.98 \\
duodenum & $\mathrm{vi}$ & 10.67 & 3.50 & 18.92 & 9.56 \\
duodenum & cry-b & 2.49 & 0.50 & 2.33 & 3.14 \\
duodenum & jun & 1.31 & 1.20 & 2.06 & 1.00 \\
duodenum & cry-total & 1.89 & 0.85 & 2.85 & 1.95 \\
jejunum & vi & 6.45 & 2.18 & 13.13 & 3.53 \\
jejunum & cry-b & 1.78 & 0.54 & 2.29 & 2.05 \\
jejunum & jun & 1.26 & 1.27 & 1.46 & 1.00 \\
ileum & vi & 4.61 & 4.00 & 8.54 & 3.53 \\
ileum & cry-b & 2.62 & 0.93 & 2.88 & 2.89 \\
ileum & jun & 1.96 & 1.36 & 2.50 & 1.96 \\
colon & cry-a & 0.80 & 0.25 & 1.10 & 0.80 \\
colon & cry-b & 1.95 & 0.66 & 2.00 & 1.98 \\
\hline
\end{tabular}

Medians of Foxp3+ lymphocytes per group are given as cells/62 $500 \mu \mathrm{m}^{2}$. Total $=$ all dogs disregarding their age. la pro = lamina propria. vi $=$ villus. cry$\mathrm{b}=$ basal crypt area. jun = villus-crypt junction. cry-total = total crypt area. cry-a $=$ apical crypt area.

\section{Foxp3 expression in canine gastrointestinal diseases}

Numbers of Foxp3 positive intestinal lymphocytes of dogs with gastrointestinal diseases are summarised in Table 4 given as medians per group. In dogs suffering from IBD, Foxp3-expressing Tregs of duodenal villi were significantly decreased in cases with lymphoplasmacytic infiltration $(p<0.001)$ and in those predominated by eosinophilic inflammation $(p<0.01)$ compared to controls (Figure 4a). No differences in Foxp3 expression were detected between cases with lymphoplasmacytic and eosinophilic infiltrations. Indeed, differences in Foxp3 expression between dogs with IBD and control animals were absent in duodenal crypt area, gastric fundus, and colonic lamina propria. Regarding the Spearman's rank correlation coefficient, there was no significant correlation between the number of Foxp3-expressing lamina propria lymphocytes and the WSAVA score in the stomach, duodenum, and colon of dogs with IBD.

In dogs with intestinal nematode infection, Foxp3 expression was significantly increased in the duodenal villus compared to controls $(p<0.05$, Figure $4 \mathrm{~b})$. However, no significant differences in the number of Tregs were present in the gastric fundus, the duodenal crypt area, and the colonic mucosa in animals with parasite infections compared to healthy individuals.

\section{Discussion}

Intestinal immune regulation including development of oral tolerance is of great importance for the maintenance of gut homeostasis [90]. Concerning this, Tregs occupy a pivotal role in cell-mediated immunosuppression $[5,6]$. Therefore, the aim of the study was to investigate the expression of Foxp3 in canine GALT of healthy and gastrointestinal diseased dogs.

Animals lacking clinical and pathomorphological signs of gastrointestinal diseases were used as healthy controls. Interestingly, minimal histopathological findings were 

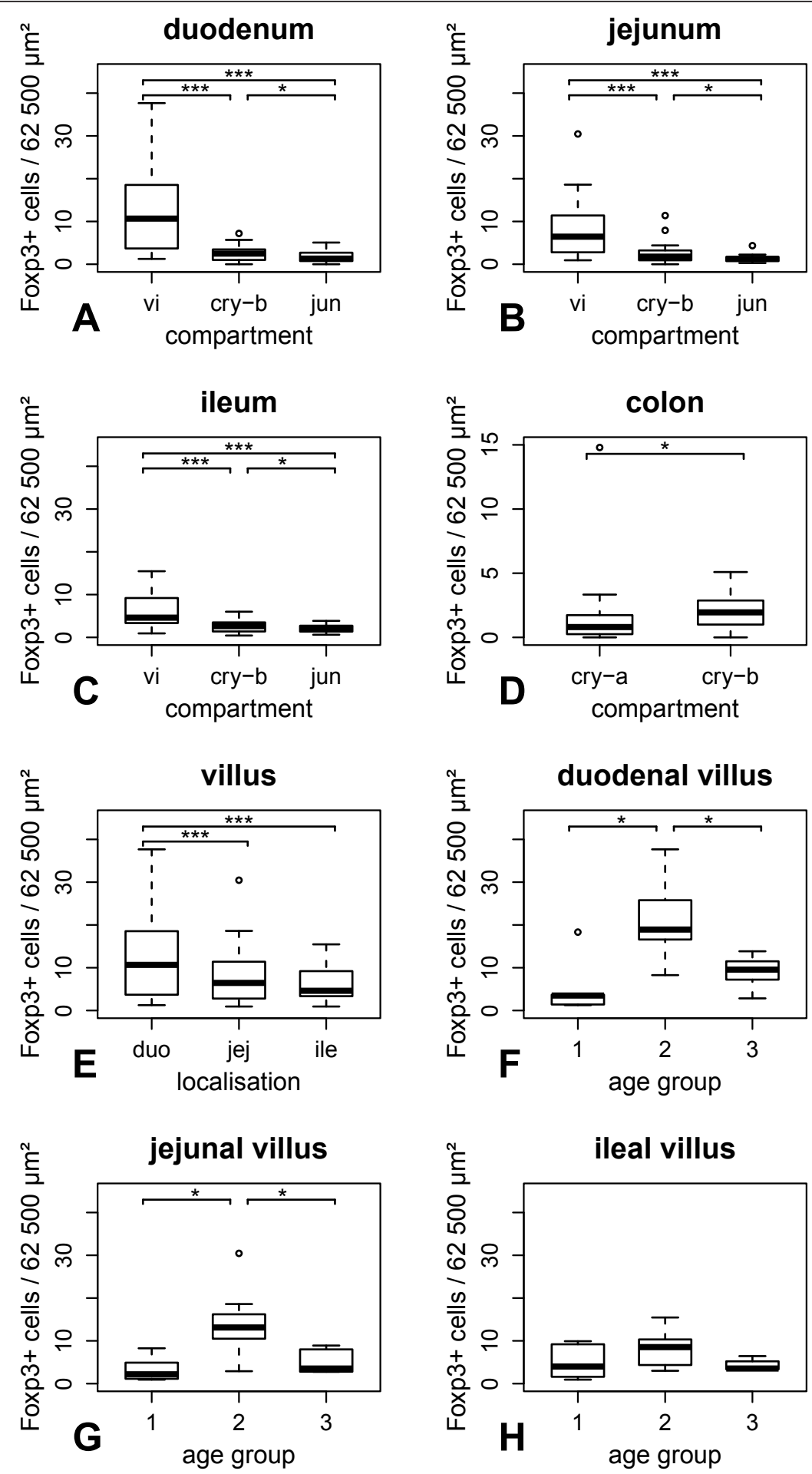

Figure 3 Intestinal Foxp3 expression in dogs without gastrointestinal diseases. Without consideration of their age, numbers of lamina propria Foxp3-positive lymphocytes were significantly increased in the villus compared to the basal crypt area as well as the villus-crypt junction and the density of Foxp3-positive lymphocytes was significantly higher in the basal crypt area than in the villus-crypt junction (A-C). In the colon, Foxp3-positive cells were increased in the basal crypt area compared to the apical part (D). Regarding the villus, lamina propria Foxp3-positive cells were significantly decreased in the jejunum and the ileum compared to the duodenum in healthy dogs disregarding their age (E). Concerning age-related changes, numbers of villus Foxp3-positive lymphocytes were significantly increased in middle-aged dogs compared to juvenile as well as old animals in the duodenum and the jejunum (F-G). In contrast, age-related changes were absent in the ileum $(H)$. vi $=$ villus. $c r y-b=$ basal crypt area. jun = villus-crypt junction. $c r y-a=$ apical crypt area. duo = duodenum. jej $=$ jejunum. ile $=\| l e u m .1=$ juvenile. $2=$ middle-aged. $3=$ old. $^{*}=p<0.05 .{ }^{* *}=p<0.001$. 
Table 4 Foxp3 expressing lymphocytes in dogs suffering from gastrointestinal diseases.

\begin{tabular}{cccccc}
\hline Localisation & Compartment & IBD total & IBD-E & IBD-LP & Nematode \\
\hline stomach & la pro & 0.85 & 1.00 & 0.70 & 1.90 \\
duodenum & vi & 4.13 & 4.37 & 1.85 & 21.06 \\
duodenum & cry-total & 1.41 & 1.81 & 0.57 & 3.16 \\
colon & cry-a & 1.63 & 2.38 & 1.50 & 2.02 \\
colon & cry-b & 2.81 & 3.00 & 1.60 & 1.86 \\
\hline
\end{tabular}

Medians of Foxp3+ lymphocytes per group are given as cells/62 $500 \mu \mathrm{m}^{2}$. la pro = lamina propria. vi $=$ villus. cry-total $=$ total crypt area. cry-a $=$ apical crypt area. cry-b = basal crypt area. IBD-E = IBD dominated by eosinophilic inflammation. IBD-LP = IBD characterised by lymphoplasmacytic infiltration.

present in the gastrointestinal tract of these dogs. Due to the absence of clinical and morphological correlates, these findings were interpreted as background variances of the canine gut. Although several reports on age-related changes and immunosenescence in dogs [91] would suggest an increasing inflammatory background in the canine elderly, no differences between the WSAVA scores of different age groups were observed. In contrast, WSAVA scores were significantly increased in dogs with gastrointestinal diseases compared to controls.

Immunohistochemically, application of anti-Foxp3 antibodies produced clear nuclear staining of cells revealing distinct lymphocyte morphology. Although Foxp3 has been established as a specific marker for classical Tregs further characterised by the expression of CD4 and CD25, heterogeneity of this cell population has been described [92]. In dogs, recent analyses on canine Tregs illustrate CD4-positive cells with intermediate Foxp3 expression and authors postulate that they are activated heterogeneous conventional T cells instead of Tregs [80]. In our study, differences in staining intensity for Foxp3 were noticed immunohistochemically. This suggests differences in Foxp3 expression in situ supporting the concept of canine Treg heterogeneity. However, this result could also be due to the localisation of Tregs in different tissue layers and needs to be further investigated.

Structured lymphoid tissue in the intestine plays a crucial role in mucosal immunology especially in induction and gut homing of intestinal Tregs and therefore for the establishment of oral tolerance [13,93]. The high density of Foxp3-expressing lymphocytes in those areas suggests similar roles of these anatomical compartments in dogs.

Additionally, Foxp3 was expressed by intraepithelial lymphocytes (IEL). It is well established that canine IEL are mainly characterised by the expression of CD8. However, less than 15 percent of these cells are CD4-positive [94]. Although most canine Tregs are known to express CD4, CD25, and Foxp3, a minor subpopulation of CD8positive lymphocytes with strong Foxp3 expression is described [80]. In spite of their correct phenotype, our results confirm the immunoregulatory phenotype of canine IEL, which has recently been observed in vitro [94].

Furthermore, Foxp3-positive lymphocytes were present in the lamina propria. Concerning different compartments (vertical distribution), Tregs were significantly increased in the villus lamina propria compared to basal crypt area and villus-crypt junction. Previous studies about intestinal $\mathrm{T}$ cells in dogs report similar differences in their distribution [95-97]. Referring to this, a stronger exposition of the intestinal apical surface to luminal antigens is discussed. Analogously, increasing numbers of Tregs in the villus area may be related to the great importance of immunoregulation in areas characterised by high antigenic load, antigen sampling by dendritic cells, and priming of immune responses.
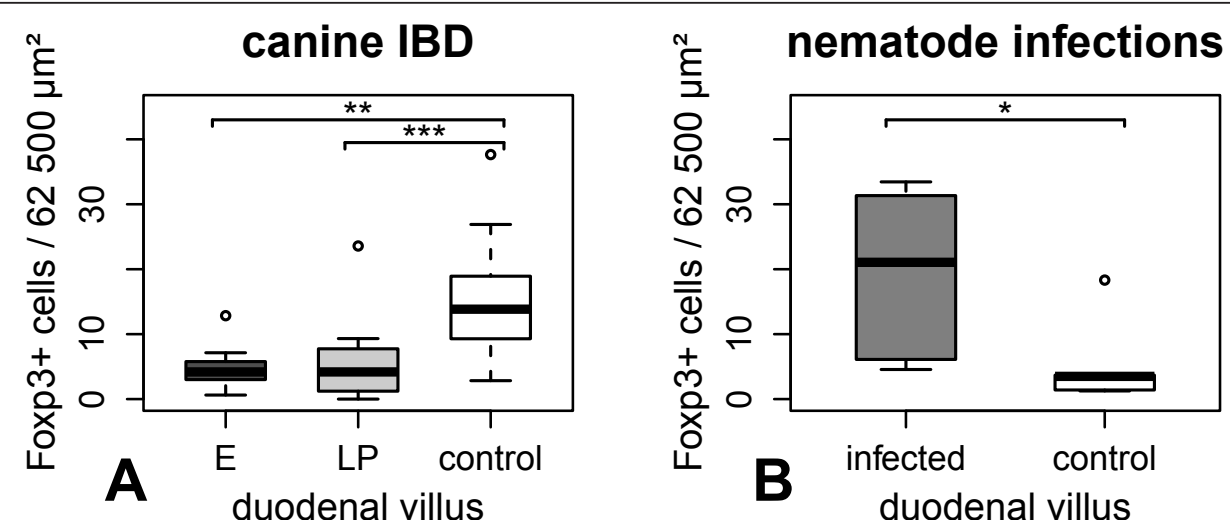

Figure 4 Intestinal Foxp3 expression in dogs suffering from gastrointestinal diseases. In canine IBD (age ranged from 2.00 to 7.22 years), Foxp3-positive cells of the duodenal villus were significantly decreased in cases with lymphoplasmacytic infiltration and in those predominated by eosinophilic inflammation compared to middle-aged controls (A). In dogs with spontaneous intestinal nematode infection (age ranged from 0.18 to 1.25 years), Foxp3 expression was significantly increased in the duodenal villus compared to juvenile healthy animals (B). $E=I B D$ dominated by eosinophilic inflammation. $\mathrm{LP}=\mathrm{IBD}$ characterised by lymphoplasmacytic infiltration. ${ }^{*}=p<0.05 .{ }^{* *}=p<0.01 .{ }^{* * *}=p<0.001$. 
Additionally, the numbers of Foxp3-positive cells were significantly higher in the basal crypt area than in the villus-crypt junction. This finding was in contrast to previous observations of a constant increase in CD3-positive cells towards the villus tip [95-97]. Possibly, the increase in Tregs in the basal crypt area compared to the villuscrypt junction is due to increased numbers of IgA-secreting plasma cells towards the crypt [96] requiring a more intense local tuning of immunological tolerance in basal areas.

Interestingly, a vertical decline in Tregs was found in the colonic mucosa since the numbers of Foxp3-positive lymphocytes were significantly lower in the apical crypt area than in the basal part. Potentially, this is related to general differences of colonic Tregs in comparison to those located in the small intestine highlighting the heterogeneity of regulatory $\mathrm{T}$ cells. Otherwise, these differences may be due to the individual anatomy and physiology of the small and large intestines. However, further studies are needed to confirm possible differences in the vertical distribution of lymphocytes in the colonic mucosa and to evaluate its relevance.

Concerning the horizontal distribution of Tregs along the small intestinal villus, numbers of Foxp3-positive lymphocytes were significantly decreased from duodenal to jejunal as well as to ileal mucosa. In contrast to this, no horizontal differences in the expression of CD3, CD4, or CD8 have been reported $[95,97]$. The horizontal decline in expression of Foxp3 may be explained by decreasing amounts of food antigens progressively destroyed along the small intestine, although the numbers of bacteria progressively increase from the duodenum to the large bowel [98]. Regarding the lower frequencies of Tregs at the luminal site of the colonic mucosa compared to those in the small intestine, it is possible that food proteins are more potent generators of intestinal Tregs than commensal bacteria. In mice, it has recently been shown that $\mathrm{T}$ cell receptors of colonic Tregs differ from those used by Tregs in other locations [99]. Therefore, canine colonic Tregs may generally differ from those in other areas including the small intestine.

In healthy dogs, age-related changes in Foxp3 expression were observed since Tregs increased in middle-aged animals compared to juvenile as well as older individuals. Age-dependent alterations of the immune system are well-known in companion animals $[91,100]$ and several reports on alterations of the canine gastrointestinal tract concerning different age groups exist $[97,101,102]$. For instance, intestinal lamina propria CD3-positive $\mathrm{T}$ cells and macrophages decline in older animals, whereas IgAcontaining plasma cells increase with age [97]. Although age-related differences in Tregs are controversially discussed [103] and only age groups with small numbers of animals ( 5 to 7 dogs per age group) were examined in this study, our data suggest an increase of intestinal
Tregs in middle-age dogs that may be an indication for an increase of oral tolerance in these dogs compared to juvenile individuals. Nevertheless, the numbers of Tregs may change in the canine gut during the first year of life since the canine immune system including the GALT undergoes maturation during this period. Additionally, the decline in Foxp3 expression in old animals could be a sign of immunosenescence and could possibly mean a loss of oral tolerance in the canine elderly.

Although age-related changes in Foxp3 expression were of statistical significance in this study, further investigations are needed to confirm these results using higher numbers of animals and to check the course of Tregs in juvenile dogs.

Dysregulation of mucosal immunology including a failure of oral tolerance against commensal bacteria and food proteins seems to play a crucial role in the pathogenesis of both human and canine IBD $[36,104]$. As it is already known, depletion of regulatory $\mathrm{T}$ cells leads to chronic colitis in immunodeficient mice [11]. Furthermore, intravenous application of Tregs can cure established intestinal inflammation in animal models for experimental colitis $[105,106]$. In Long-Evans Cinnamon rats (deficient in thymocyte development) showing spontaneous development of IBD-like colitis, Tregs are significantly reduced in the colonic lamina propria [9]. Interestingly, Foxp3-positive Tregs are present at higher densities in the lamina propria of human patients suffering from IBD than in healthy controls [107-109]. This indicates an impaired function of Tregs or a resistance of $\mathrm{T}$ effector cells to Treg-mediated suppression instead of a numerical aberrance in the Treg population. However, investigated dogs suffering form IBD revealed a significant reduction of Foxp3 expression in the duodenal villi in cases of both eosinophilic and lymphoplasmacytic inflammation compared to controls. Further studies using full-thickness intestinal samples are needed to check if similar differences in Tregs are also present in the jejunum and ileum in canine IBD. Interestingly, no differences in Treg numbers were present in the stomach and colon of dogs with IBD in comparison to controls. This may be an indication of different roles of small intestinal Tregs compared to those located in the stomach and the colon for canine IBD. Under physiological conditions, enrichment of Tregs in areas of inflammation is mediated by a negative feedback mechanism via IL- 2 produced by $T$ effector cells ensuring a balanced cooperation between protective immune responses and immunosuppression [110]. Therefore, our results may be a sign of a primary defect in Treg homeostasis leading to chronic inflammation due to a lack of immune regulation as a pathogenetic factor in canine IBD. Further studies on Treg function are needed to confirm this possibility.

Unlike dogs with IBD, dogs with intestinal nematode infection revealed increased numbers of Tregs in the 
duodenal villus compared to controls. Interestingly, no differences in Treg numbers were present in the stomach and colon of dogs with nematode infection in comparison to controls. Therefore, further studies are needed to determine whether this is related to the nematode species and its localisation in the gut or due to general differences in canine Tregs in the small intestine compared to those located in the stomach and colon. Intestinal parasites are known to trigger Th2 dominated immune responses and cause down regulation of immune responses ensuring a better survival in their hosts [42,111]. Particularly, suspension of Treg activity leads to exacerbated intestinal pathology and enhances parasite clearance $[43,44]$. Furthermore, helminth secretions are able to induce Foxp3 expression and enhance the regulatory function of $\mathrm{T}$ cells [46]. Therefore, our results suggest a parasite-related increase in intestinal immune regulation, although IL-2 mediated enrichment of Tregs may also be involved. Interestingly, parasites are discussed as potential strategies for the treatment of human IBD due to their ability to prevent intestinal pathology and their immunoregulatory properties $[47,48]$.

This study elucidates that regulatory $\mathrm{T}$ cells are expressed in the canine GALT with a decline of Tregs from the villus to the crypt and age-related changes suggesting a progressive establishment of oral tolerance and immunosenescence including decreased oral tolerance in the canine elderly. A reduced number of Tregs in canine IBD suggests a defect in Treg homeostasis leading to a loss of oral tolerance. In addition, Tregs were enriched in the duodenal villi of dogs with intestinal nematode infection indicating a parasite-induced enhancement of intestinal immune regulation.

\section{Acknowledgements}

We thank Dr P. Wefstaedt (Small Animal Clinic of the University of Veterinary Medicine, Hannover) for providing endoscopical biopsies from diseased dogs and B. Buck and K.P. Kuhlmann for excellent technical assistance. Additionally, we thank Dr M. Beyerbach for advising on statistical analyses. Johannes Junginger received a scholarship from the Studienstiftung des deutschen Volkes.

\section{Author details}

'Institute of Pathology, University of Veterinary Medicine Hannover, Bünteweg 17, D-30559 Hannover, Germany. ${ }^{2}$ Small Animal Clinic DuisburgAsterlagen, Dr.-Detlev-Karsten-Rohwedder-Str. 11, D-47228 DuisburgRheinhausen, Germany. ${ }^{3}$ Small Animal Clinic, University of Veterinary Medicine Hannover, Bünteweg 9, D-30559 Hannover, Germany.

\section{Authors' contributions}

$J$ was involved in the study design and the collection and processing of material and performed the histopathological evaluation, immunohistochemical procedures, slide evaluation, statistical analyses Furthermore he wrote the manuscript. US was involved in the collection and processing of material and its histopathological evaluation. Additionally, she importantly improved the manuscript. FL and IN were involved in collecting endoscopical samples and the study design and made substantial contributions to the manuscript. MHT was involved in the study design and in writing the manuscript and gave final approval of the version to be published. All authors read and approved the final manuscript.

\section{Competing interests}

The authors declare that they have no competing interests.

Received: 31 October 2011 Accepted: 22 March 2012

Published: 22 March 2012

\section{References}

1. Atkins AM, Schofield GC: Lymphoglandular complexes in the large intestine of the dog. J Anat 1972, 113:169-178.

2. HogenEsch $H$, Felsburg PJ: Isolation and phenotypic and functional characterization of cells from Peyer's patches in the dog. Vet Immunol Immunopathol 1992, 31:1-10.

3. Stokes C, Waly N: Mucosal defence along the gastrointestinal tract of cats and dogs. Vet Res 2006, 37:281-293.

4. Ramiro-Puig E, Perez-Cano FJ, Castellote C, Franch A, Castell M: The bowel: a key component of the immune system. Rev Esp Enferm Dig 2008, 100:29-34, in Spanish.

5. Lan RY, Mackay IR, Gershwin ME: Regulatory $T$ cells in the prevention of mucosal inflammatory diseases: patrolling the border. J Autoimmun 2007, 29:272-280.

6. Sakaguchi S, Yamaguchi T, Nomura T, Ono M: Regulatory $\mathrm{T}$ cells and immune tolerance. Cell 2008, 133:775-787.

7. Sakaguchi S, Sakaguchi N, Asano M, Itoh M, Toda M: Immunologic selftolerance maintained by activated $T$ cells expressing IL-2 receptor alphachains (CD25). Breakdown of a single mechanism of self-tolerance causes various autoimmune diseases. J Immunol 1995, 155:1151-1164.

8. Bennett CL, Christie J, Ramsdell F, Brunkow ME, Ferguson PJ, Whitesell L, Kelly TE, Saulsbury FT, Chance PF, Ochs HD: The immune dysregulation, polyendocrinopathy, enteropathy, X-linked syndrome (IPEX) is caused by mutations of FOXP3. Nat Genet 2001, 27:20-21.

9. Ishimaru N, Yamada A, Kohashi M, Arakaki R, Takahashi T, Izumi K, Hayashi Y: Development of inflammatory bowel disease in Long-Evans Cinnamon rats based on CD4+CD25+Foxp3+ regulatory $\mathrm{T}$ cell dysfunction. J Immunol 2008, 180:6997-7008.

10. Moes N, Rieux-Laucat F, Begue B, Verdier J, Neven B, Patey N, Torgerson TT, Picard C, Stolzenberg MC, Ruemmele C, et al: Reduced expression of FOXP3 and regulatory T-cell function in severe forms of early-onset autoimmune enteropathy. Gastroenterology 2010, 139:770-778.

11. Veltkamp C, Ruhwald R, Giesem T, Autschbach F, Kaden I, Veltkamp R, Sartor RB, Stremmel W: CD4+CD25+ cell depletion from the normal CD4+ $T$ cell pool prevents tolerance toward the intestinal flora and leads to chronic colitis in immunodeficient mice. Inflamm Bowel Dis 2006, 12:437-446.

12. Coombes $\mathrm{J}$, Maloy $\mathrm{KJ}$ : Control of intestinal homeostasis by regulatory $\mathrm{T}$ cells and dendritic cells. Semin Immunol 2007, 19:116-126.

13. Hadis U, Wahl B, Schulz O, Hardtke-Wolenski M, Schippers A, Wagner N, Muller W, Sparwasser T, Forster R, Pabst O: Intestinal tolerance requires gut homing and expansion of FoxP3+ regulatory $\mathrm{T}$ cells in the lamina propria. Immunity 2011, 34:237-246

14. Brunkow ME, Jeffery EW, Hjerrild KA, Paeper B, Clark LB, Yasayko SA Wilkinson JE, Galas D, Ziegler SF, Ramsdell F: Disruption of a new forkhead/winged-helix protein, scurfin, results in the fatal lymphoproliferative disorder of the scurfy mouse. Nat Genet 2001, 27:68-73.

15. Fontenot JD, Gavin MA, Rudensky AY: Foxp3 programs the development and function of CD4+CD25+ regulatory T cells. Nat Immunol 2003, 4:330-336

16. Jergens AE, Moore FM, Haynes JS, Miles KG: Idiopathic inflammatory bowel disease in dogs and cats: 84 cases (1987-1990). J Am Vet Med Assoc 1992, 201:1603-1608.

17. Hall EJ, German AJ: Inflammatory Bowel Disease. In Small Animal Gastroenterology. Edited by: Steiner JM. Hannover: Schluetersche Verlagsgesellschaft; 2008:312-329.

18. Washabau RJ, Day MJ, Willard MD, Hall EJ, Jergens AE, Mansell J, Minami T, Bilzer TW: Endoscopic, biopsy, and histopathologic guidelines for the evaluation of gastrointestinal inflammation in companion animals. J Vet Intern Med 2010, 24:10-26.

19. Podolsky DK: Inflammatory bowel disease. N Engl J Med 2002, 347:417-429. 
20. Xavier RJ, Podolsky DK: Unravelling the pathogenesis of inflammatory bowel disease. Nature 2007, 448:427-434

21. Galandiuk S, Kimberling J, Al-Mishlab TG, Stromberg AJ: Perianal Crohn disease: predictors of need for permanent diversion. Ann Surg 2005, 241:796-801.

22. Williams $H$, Walker $D$, Orchard TR: Extraintestinal manifestations of inflammatory bowel disease. Curr Gastroenterol Rep 2008, 10:597-605.

23. German AJ, Hall EJ, Day MJ: Chronic intestinal inflammation and intestinal disease in dogs. J Vet Intern Med 2003, 17:8-20.

24. Craven M, Simpson JW, Ridyard AE, Chandler ML: Canine inflammatory bowel disease: retrospective analysis of diagnosis and outcome in 80 cases (1995-2002). J Small Anim Pract 2004, 45:336-342.

25. Van Kruiningen HJ, Montali RJ, Strandberg JD, Kirk RW: A granulomatous colitis of dogs with histologic resemblance to Whipple's disease. Pathol Vet 1965, 2:521-544.

26. Craven M, Mansfield CS, Simpson KW: Granulomatous colitis of boxer dogs. Vet Clin North Am Small Anim Pract 2011, 41:433-445.

27. Mansfield CS, James FE, Craven M, Davies DR, O'Hara AJ, Nicholls PK, Dogan B, MacDonough SP, Simpson KW: Remission of histiocytic ulcerative colitis in Boxer dogs correlates with eradication of invasive intramucosal Escherichia coli. J Vet Intern Med 2009, 23:964-969.

28. Bright RM, Jenkins C, DeNovo RM, McCrackin MA, Toal R: Chronic diarrhoea in a dog with regional granulomatous enteritis. J Small Anim Pract 1994, 35:423-426.

29. Lewis DC: Successful treatment of regional enteritis in a dog. J Am Anim Hosp Assoc 1995, 31:170-173.

30. Ridgway J, Jergens AE, Niyo Y: Possible causal association of idiopathic inflammatory bowel disease with thrombocytopenia in the dog. J Am Anim Hosp Assoc 2001, 37:65-74.

31. German AJ, Hall EJ, Day MJ: Relative deficiency in IgA production by duodenal explants from German shepherd dogs with small intestinal disease. Vet Immunol Immunopathol 2000, 76:25-43.

32. Hostutler RA, Luria BJ, Johnson SE, Weisbrode SE, Sherding RG, Jaeger JQ, Guilford WG: Antibiotic-responsive histiocytic ulcerative colitis in 9 dogs. J Vet Intern Med 2004, 18:499-504

33. Littler RM, Batt RM, Lloyd DH: Total and relative deficiency of gut mucosal IgA in German shepherd dogs demonstrated by faecal analysis. Vet Rec 2006, 158:334-341.

34. Kathrani A, House A, Catchpole B, Murphy A, German A, Werling D, Allenspach $\mathrm{K}$ : Polymorphisms in the TLR4 and TLR5 gene are significantly associated with inflammatory bowel disease in German shepherd dogs. PLoS One 2010, 5:e15740.

35. Kathrani A, Werling D, Allenspach K: Canine breeds at high risk of developing inflammatory bowel disease in the south-eastern UK. Vet Rec 2011, 169:635

36. Maloy KJ, Powrie F: Intestinal homeostasis and its breakdown in inflammatory bowel disease. Nature 2011, 474:298-306.

37. Allenspach K: Clinical immunology and immunopathology of the canine and feline intestine. Vet Clin North Am Small Anim Pract 2011, 41:345-360

38. Robertson ID, Thompson RC: Enteric parasitic zoonoses of domesticated dogs and cats. Microbes Infect 2002, 4:867-873.

39. Lee AC, Schantz PM, Kazacos KR, Montgomery SP, Bowman DD: Epidemiologic and zoonotic aspects of ascarid infections in dogs and cats. Trends Parasitol 2010, 26:155-161.

40. Hayden DW, Kruiningen HJ: Experimentally induced canine toxocariasis: laboratory examinations and pathologic changes, with emphasis on the gastrointestinal tract. Am J Vet Res 1975, 36:1605-1614.

41. Anthony RM, Rutitzky LI, Urban JF, Stadecker MJ, Gause WC: Protective immune mechanisms in helminth infection. Nat Rev Immunol 2007, 7:975-987.

42. Allen JE, Maizels RM: Diversity and dialogue in immunity to helminths. Nat Rev Immunol 2011, 11:375-388.

43. Taylor MD, LeGoff L, Harris A, Malone E, Allen JE, Maizels RM: Removal of regulatory $\mathrm{T}$ cell activity reverses hyporesponsiveness and leads to filarial parasite clearance in vivo. J Immunol 2005, 174:4924-4933.

44. D'Elia R, Behnke JM, Bradley JE, Else KJ: Regulatory T cells: a role in the control of helminth-driven intestinal pathology and worm survival. $J$ Immunol 2009, 182:2340-2348.

45. Othman AA, El-Shourbagy SH, Soliman RH: Kinetics of Foxp3-expressing regulatory cells in experimental Toxocara canis infection. Exp Parasitol 2011, 127:454-459.
46. Grainger JR, Smith KA, Hewitson JP, McSorley HJ, Harcus Y, Filbey K, Finney CA, Greenwood EJ, Knox DP, Wilson MS, Belkaid Y, Rudensky AY, Maizels RM: Helminth secretions induce de novo T cell Foxp3 expression and regulatory function through the TGF-beta pathway. J Exp Med 2010, 207:2331-2341.

47. Moreels TG, Pelckmans PA: Gastrointestinal parasites: potential therapy for refractory inflammatory bowel diseases. Inflamm Bowel Dis 2005, 11:178-184.

48. Ruyssers NE, De Winter BY, De Man JG, Loukas A, Herman AG, Pelckmans PA, Moreels TG: Worms and the treatment of inflammatory bowel disease: are molecules the answer? Clin Dev Immunol 2008, 2008:567314.

49. Biller BJ, Elmslie RE, Burnett RC, Avery AC, Dow SW: Use of FoxP3 expression to identify regulatory $T$ cells in healthy dogs and dogs with cancer. Vet Immunol Immunopathol 2007, 116:69-78.

50. Banham AH, Lyne L, Scase TJ, Blacklaws BA: Monoclonal antibodies raised to the human FOXP3 protein can be used effectively for detecting Foxp3(+) T cells in other mammalian species. Vet Immunol Immunopathol 2009, 127:376-381.

51. Garden OA, Pinheiro D, Cunningham F: All creatures great and small: regulatory $\mathrm{T}$ cells in mice, humans, dogs and other domestic animal species. Int Immunopharmacol 2011, 11:576-588.

52. Vahlenkamp TW, Tompkins MB, Tompkins WA: Feline immunodeficiency virus infection phenotypically and functionally activates immunosuppressive CD4+CD25+ T regulatory cells. J Immunol 2004, 172:4752-4761.

53. Joshi A, Vahlenkamp TW, Garg H, Tompkins WA, Tompkins MB: Preferential replication of FIV in activated CD4(+)CD25(+)T cells independent of cellular proliferation. Virology 2004, 321:307-322

54. Lankford S, Petty C, LaVoy A, Reckling S, Tompkins W, Dean GA: Cloning of feline FOXP3 and detection of expression in CD4+CD25+ regulatory $T$ cells. Vet Immunol Immunopathol 2008, 122:159-166.

55. Mexas AM, Fogle JE, Tompkins WA, Tompkins MB: CD4+CD25+ regulatory T cells are infected and activated during acute FIV infection. Vet Immunol Immunopathol 2008, 126:263-272.

56. Kaser T, Gerner W, Hammer SE, Patzl M, Saalmuller A: Phenotypic and functional characterisation of porcine $\mathrm{CD} 4(+) \mathrm{CD} 25$ (high) regulatory $\mathrm{T}$ cells. Vet Immunol Immunopathol 2008, 122:153-158.

57. Kaser T, Gerner W, Hammer SE, Patzl M, Saalmuller A: Detection of Foxp3 protein expression in porcine T lymphocytes. Vet Immunol Immunopathol 2008, 125:92-101.

58. Bolzer K, Kaser T, Saalmuller A, Hammer SE: Molecular characterisation of porcine Forkhead-box p3 (Foxp3). Vet Immunol Immunopathol 2009, 132:275-281

59. Georgieva R: Dynamics of T-suppressor and T-helper lymphocytes and haemolytic plaque-forming cells during normal pregnancy in the sow. $J$ Reprod Immunol 1984, 6:151-156.

60. Mezrich JD, Kesselheim JA, Johnston DR, Yamada K, Sachs DH, Madsen JC: The role of regulatory cells in miniature swine rendered tolerant to cardiac allografts by donor kidney cotransplantation. Am J Transplant 2003, 3:1107-1115.

61. Wu A, Yamada K, lerino FL, Vagefi PA, Sachs DH: Regulatory mechanism of peripheral tolerance: in vitro evidence for dominant suppression of host responses during the maintenance phase of tolerance to renal allografts in miniature swine. Transpl Immunol 2003, 11:367-374.

62. Wu A, Yamada K, Baron C, Mathes DW, Monajati LM, Vagefi PA, Sachs DH: Detection of regulatory cells as an assay for allograft tolerance in miniature swine. J Heart Lung Transplant 2004, 23:210-217.

63. Wongyanin P, Buranapraditkun S, Chokeshai-Usaha K, Thanawonguwech R, Suradhat S: Induction of inducible CD4+CD25+Foxp3+ regulatory T lymphocytes by porcine reproductive and respiratory syndrome virus (PRRSV). Vet Immunol Immunopathol 2010, 133:170-182.

64. Silva-Campa E, Flores-Mendoza L, Resendiz M, Pinelli-Saavedra A, MataHaro V, Mwangi W, Hernandez J: Induction of T helper 3 regulatory cells by dendritic cells infected with porcine reproductive and respiratory syndrome virus. Virology 2009, 387:373-379.

65. Seo KS, Davis WC, Hamilton MJ, Park YH, Bohach GA: Development of monoclonal antibodies to detect bovine FOXP3 in PBMCs exposed to a staphylococcal superantigen. Vet Immunol Immunopathol 2009, 128:30-36. 
66. Gerner W, Stadler M, Hammer SE, Klein D, Saalmuller A: Sensitive detection of Foxp3 expression in bovine lymphocytes by flow cytometry. Vet Immunol Immunopathol 2010, 138:154-158.

67. Hoek A, Rutten VP, Kool J, Arkesteijn GJ, Bouwstra RJ, Van Rhijn I, Koets AP: Subpopulations of bovine WC1(+) gammadelta T cells rather than CD4 (+)CD25(high) Foxp3(+) T cells act as immune regulatory cells ex vivo. Vet Res 2009, 40:6.

68. McNeilly TN, Mclntyre J, Frew D, Griffiths DJ, Wattegedera SR, van den Broek A, Huntley JF: Infestation of sheep with Psoroptes ovis, the sheep scab mite, results in recruitment of Foxp3(+) T cells into the dermis. Parasite Immunol 2010, 32:361-369.

69. Hamza E, Steinbach F, Marti E: CD4(+)CD25(+) T cells expressing FoxP3 in Icelandic horses affected with insect bite hypersensitivity. Vet Immunol Immunopathol, doi:10.1016/j.vetimm.2011.05.033.

70. Porter CM, Horvath-Arcidiacono JA, Singh AK, Horvath KA, Bloom ET, Mohiuddin MM: Characterization and expansion of baboon CD4+CD25+ Treg cells for potential use in a non-human primate xenotransplantation model. Xenotransplantation 2007, 14:298-308.

71. Singh AK, Horvath KA, Mohiuddin MM: Rapamycin promotes the enrichment of CD4(+)CD25(hi)FoxP3(+) T regulatory cells from naive CD4(+) T cells of baboon that suppress antiporcine xenogenic response in vitro. Transplant Proc 2009, 41:418-421.

72. Allers K, Loddenkemper C, Hofmann J, Unbehaun A, Kunkel D, Moos V, Kaup FJ, Stahl-Hennig C, Sauermann U, Epple HJ, Schneider T: Gut mucosal FOXP3+ regulatory CD4+ T cells and Nonregulatory CD4+ T cells are differentially affected by simian immunodeficiency virus infection in rhesus macaques. J Virol 2010, 84:3259-3269.

73. Manigold T, Shin EC, Mizukoshi E, Mihalik K, Murthy KK, Rice CM, Piccirillo CA, Rehermann B: Foxp3+CD4+CD25+ T cells control virusspecific memory $T$ cells in chimpanzees that recovered from hepatitis $C$. Blood 2006, 107:4424-4432

74. Seibel H, Stimmer L, Siebert U, Beineke A: Immunohistochemical characterization of selected cell markers for the detection of hematopoietic cells in formalin-fixed, paraffin wax-embedded lymphoid tissues of harbor seals (Phoca vitulina) and walruses (Odobenus rosmarus rosmarus). Vet Immunol Immunopathol 2010, 137:305-309.

75. Mitra S, Alnabulsi A, Secombes CJ, Bird S: Identification and characterization of the transcription factors involved in T-cell development, t-bet, stat6 and foxp3, within the zebrafish, Danio rerio. FEBS J 2010, 277:128-147.

76. Weiden PL, Storb R, Tsoi MS, Graham TC, Lerner KG, Thomas ED: Infusion of donor lymphocytes into stable canine radiation chimeras: implications for mechanism of transplantation tolerance. J Immunol 1976, 116:1212-1219.

77. Mizuno T, Suzuki R, Umeki S, Okuda M: Crossreactivity of antibodies to canine CD25 and Foxp3 and identification of canine CD4+CD25 +Foxp3 + cells in canine peripheral blood. J Vet Med Sci 2009, 71:1561-1568.

78. Rissetto KC, Rindt H, Selting KA, Villamil JA, Henry CJ, Reinero CR: Cloning and expression of canine CD25 for validation of an anti-human CD25 antibody to compare $T$ regulatory lymphocytes in healthy dogs and dogs with osteosarcoma. Vet Immunol Immunopathol 2010, 135:137-145.

79. Abrams VK, Hwang B, Lesnikova M, Gass MJ, Wayner E, Castilla-Llorente C, Georges GE, Nash RA: A novel monoclonal antibody specific for canine CD25 (P4A10): Selection and evaluation of canine Tregs. Vet Immunol Immunopathol 2009, 135:257-265.

80. Pinheiro D, Singh $Y$, Grant CR, Appleton RC, Sacchini F, Walker KR, Chadbourne AH, Palmer CA, Armitage-Chan E, Thompson I, Williamson L, Cunningham F, Garden OA: Phenotypic and functional characterization of a CD4(+) CD25(high) FOXP3(high) regulatory T-cell population in the dog. Immunology 2011, 132:111-122.

81. O'Neill K, Guth A, Biller B, Elmslie R, Dow S: Changes in regulatory T cells in dogs with cancer and associations with tumor type. J Vet Intern Med 2009, 23:875-881.

82. Horiuchi $Y$, Tominaga M, Ichikawa M, Yamashita M, Okano K, Jikumaru Y, Nariai Y, Nakajima Y, Kuwabara M, Yukawa M: Relationship between regulatory and type $1 \mathrm{~T}$ cells in dogs with oral malignant melanoma. Microbiol Immunol 2010, 54:152-159.

83. Tominaga M, Horiuchi Y, Ichikawa M, Yamashita M, Okano K, Jikumaru Y, Nariai Y, Kadosawa T: Flow cytometric analysis of peripheral blood and tumor-infiltrating regulatory $\mathrm{T}$ cells in dogs with oral malignant melanoma. J Vet Diagn Invest 2010, 22:438-441.
84. Horiuchi $Y$, Tominaga M, Ichikawa M, Yamashita M, Jikumaru Y, Nariai $Y$, Nakajima Y, Kuwabara M, Yukawa M: Increase of regulatory $T$ cells in the peripheral blood of dogs with metastatic tumors. Microbiol Immunol 2009, 53:468-474.

85. Keppel KE, Campbell KL, Zuckermann FA, Greeley EA, Schaeffer DJ, Husmann RJ: Quantitation of canine regulatory T cell populations, serum interleukin-10 and allergen-specific lgE concentrations in healthy control dogs and canine atopic dermatitis patients receiving allergen-specific immunotherapy. Vet Immunol Immunopathol 2008, 123:337-344.

86. Veenhof EZ, Rutten VP, van Noort R, Knol EF, Willemse T: Evaluation of Tcell activation in the duodenum of dogs with cutaneous food hypersensitivity. Am J Vet Res 2010, 71:441-446.

87. Veenhof EZ, Knol EF, Schlotter YM, Vernooij JC, Rutten VP, Willemse T: Characterisation of $\mathrm{T}$ cell phenotypes, cytokines and transcription factors in the skin of dogs with cutaneous adverse food reactions. Vet J 2011, 187:320-324.

88. Day MJ, Bilzer T, Mansell J, Wilcock B, Hall EJ, Jergens A, Minami T, Willard M, Washabau R: Histopathological standards for the diagnosis of gastrointestinal inflammation in endoscopic biopsy samples from the dog and cat: a report from the World Small Animal Veterinary Association Gastrointestinal Standardization Group. J Comp Pathol 2008, 138(Suppl 1):1-43.

89. Boozer LB, Davis TW, Borst LB, Zseltvay KM, Olby NJ, Mariani CL: Characterization of Immune Cell Infiltration Into Canine Intracranial Meningiomas. Vet Pathol, doi: 10.1177/0300985811417249.

90. Garrett WS, Gordon Jl, Glimcher LH: Homeostasis and inflammation in the intestine. Cell 2010, 140:859-870.

91. Day MJ: Ageing, immunosenescence and inflammageing in the dog and cat. J Comp Pathol 2010, 142(Suppl 1):60-69.

92. Murai M, Krause $P$, Cheroutre $H$, Kronenberg M: Regulatory T-cell stability and plasticity in mucosal and systemic immune systems. Mucosal Immunol 2010, 3:443-449.

93. Kraal G, Samsom JN, Mebius RE: The importance of regional lymph nodes for mucosal tolerance. Immunol Rev 2006, 213:119-130.

94. Luckschander N, Pfammatter NS, Sidler D, Jakob S, Burgener IA, Moore PF, Zurbriggen A, Corazza N, Brunner T: Phenotyping, functional characterization, and developmental changes in canine intestinal intraepithelial lymphocytes. Vet Res 2009, 40:58.

95. Elwood CM, Hamblin AS, Batt RM: Quantitative and qualitative immunohistochemistry of T cell subsets and MHC class II expression in the canine small intestine. Vet Immunol Immunopathol 1997, 58:195-207.

96. German AJ, Hall EJ, Day MJ: Analysis of leucocyte subsets in the canine intestine. J Comp Pathol 1999, 120:129-145.

97. Kleinschmidt S, Meneses F, Nolte I, Hewicker-Trautwein M: Distribution of mast cell subtypes and immune cell populations in canine intestines: evidence for age-related decline in T cells and macrophages and increase of IgA-positive plasma cells. Res Vet Sci 2008, 84:41-48.

98. Smith HW: Observations on the flora of the alimentary tract of animals and factors affecting its composition. J Pathol Bacteriol 1965, 89:95-122.

99. Lathrop SK, Bloom SM, Rao SM, Nutsch K, Lio CW, Santacruz N Peterson DA, Stappenbeck TS, Hsieh CS: Peripheral education of the immune system by colonic commensal microbiota. Nature 2011, 478:250-254.

100. Day MJ: Immune system development in the dog and cat. J Comp Pathol 2007, 137(Suppl 1):10-15.

101. Baum B, Meneses F, Kleinschmidt S, Nolte I, Hewicker-Trautwein M: Agerelated histomorphologic changes in the canine gastrointestinal tract: a histologic and immunohistologic study. World J Gastroenterol 2007, 13:152-157.

102. Kleinschmidt S: Investigations about age-related changes in the canine gastrointestinal mucosal immune system and about the role of mast cell subtypes and immune cells in dogs with inflammatory bowel disease (IBD). PhD thesis University of Veterinary Medicine, Hannover, Pathology Department; 2007.

103. Gruver AL, Hudson LL, Sempowski GD: Immunosenescence of ageing. J Pathol 2007, 211:144-156.

104. Cerquetella M, Spaterna A, Laus F, Tesei B, Rossi G, Antonelli E, Villanacci V, Bassotti G: Inflammatory bowel disease in the dog: differences and similarities with humans. World J Gastroenterol 2010, 16:1050-1056. 
105. Liu H, Hu B, Xu D, Liew FY: CD4+CD25+ regulatory T cells cure murine colitis: the role of IL-10, TGF-beta, and CTLA4. J Immunol 2003, 171:5012-5017.

106. Mottet C, Uhlig HH, Powrie F: Cutting edge: cure of colitis by CD4+CD25+ regulatory T cells. J Immunol 2003, 170:3939-3943.

107. Maul J, Loddenkemper C, Mundt P, Berg E, Giese T, Stallmach A, Zeitz M, Duchmann R: Peripheral and intestinal regulatory CD4+ CD25(high) T cells in inflammatory bowel disease. Gastroenterology 2005, 128:1868-1878.

108. Uhlig HH, Coombes J, Mottet C, Izcue A, Thompson C, Fanger A, Tannapfel A, Fontenot JD, Ramsdell F, Powrie F: Characterization of Foxp3 $+\mathrm{CD} 4+\mathrm{CD} 25+$ and $\mathrm{IL}-10$-secreting $\mathrm{CD} 4+\mathrm{CD} 25+\mathrm{T}$ cells during cure of colitis. J Immunol 2006, 177:5852-5860.

109. Yu QT, Saruta M, Avanesyan A, Fleshner PR, Banham AH, Papadakis KA: Expression and functional characterization of FOXP3 $+\mathrm{CD} 4+$ regulatory $T$ cells in ulcerative colitis. Inflamm Bowel Dis 2007, 13:191-199.

110. Almeida AR, Zaragoza B, Freitas AA: Indexation as a novel mechanism of lymphocyte homeostasis: the number of CD4+CD25+ regulatory T cells is indexed to the number of IL-2-producing cells. J Immunol 2006, 177:192-200

111. Maizels RM, Yazdanbakhsh M: Immune regulation by helminth parasites: cellular and molecular mechanisms. Nat Rev Immunol 2003, 3:733-744.

doi:10.1186/1297-9716-43-23

Cite this article as: Junginger et al:: Immunohistochemical investigation of Foxp3 expression in the intestine in healthy and diseased dogs. Veterinary Research 2012 43:23.

\section{Submit your next manuscript to BioMed Central} and take full advantage of:

- Convenient online submission

- Thorough peer review

- No space constraints or color figure charges

- Immediate publication on acceptance

- Inclusion in PubMed, CAS, Scopus and Google Scholar

- Research which is freely available for redistribution

Submit your manuscript at www.biomedcentral.com/submit
Biomed Central 